\title{
PEMANFAATAN LAHAN SALIN TADAH HUJAN UNTUK BUDIDAYA SORGUM
}

\section{Utilization Of Rainfed Saline Land For Sorghum Cultivation}

\author{
Usnawiyah $^{1}{ }^{*}$, Khaidir ${ }^{1}$, Muhammad Yusuf ${ }^{1}$, Elvira Sari Dewi ${ }^{1}$ \\ ${ }^{1}$ Program Studi Agroekoteknologi, Fakultas Pertanian, Universitas Malikussaleh \\ Jl. Cot Tengku Nie Reuleut, Muara Batu, Aceh Utara, Lhokseumawe 24355 \\ *)Corresponding author: usnawiyah@unimal.ac.id
}

\begin{abstract}
ABSTRAK
Indonesia diperkirakan memiliki sekitar 440.330 ha lahan yang terkategorikan sebagai lahan salin. Salah satu contoh dapat dilihat di kawasan pesisir Aceh yang kondisi ini diperparah setelah terjadinya tsunami 16 tahun silam. Lahan yang tertimbun lumpur tsunami menunjukkan kadar garam (Na) di lahan sawah yang terendam air laut mencapai $1.000 \mathrm{ppm}$. Sorgum sebagai tanaman C4 relatif mudah beradaptasi dengan daerah panas atau kering bahkan lahan dengan kandungan salinitas tinggi sekalipun. Penelitian ini bertujuan untuk memberdayakan lahan salin untuk budidaya sorgum sebagai upaya deversifikasi dan swasembada pangan diera kenormalan baru dan mengkaji ketahanan beberapa varietas sorgum terhadap salinitas di daerah berpotensi kering tinggi. Penelitian ini dilakukan di Desa Blang Nibong Kecamatan Samudera Kabupaten Aceh Utara, Provinsi Aceh menggunakan Rancangan Acak Kelompok faktorial yang terdiri atas sawah tadah hujan salin dekat pantai (berjarak lebih kurang 100) dan jarak 300 meter dari pantai. Dua varietas yang diuji yaitu Numbu dan Samurai 2 menunjukkan respon berbeda pada parameter pertumbuhan dan hasil. Numbu dapat disimpulkan memiliki ketahanan yang lebih baik terhadap lahan dengan salinitas tinggi dibandingkan dengan Samurai 2.
\end{abstract}

Kata Kunci: sorgum, salin, tadah hujan, marjinal, pangan alternatif

\begin{abstract}
Indonesia is estimated to have around 440,330 ha of land which is categorized as saline land. One example can be seen in the coastal area of Aceh which was aggravated after the tsunami 16 years ago. Farms buried in the tsunami mud showed levels of salt $(\mathrm{Na})$ reaching 1,000 ppm. Sorghum as a $\mathrm{C} 4$ plant is relatively easy to adapt to hot or dry areas and on land with high salinity content. This study aims to utilize saline land for sorghum cultivation as an effort to deversify and self-sufficiency food in the new normal era and to assess the resistance of several varieties of sorghum to salinity in drought-prone areas. This research was conducted in Blang Nibong Village, Samudera District, North Aceh Regency, Aceh Province using a factorial randomized block design consisting of saline rain-fed rice fields near the coast (approximately 100 meters away) and a distance of 300 meters from the beach. The two varieties tested, namely Numbu and Samurai2, showed different responses to growth and yield parameters. Numbu showed better performance on morphological, physiological and harvest aspects. It can be concluded that Numbu has better resistance to land with high salinity compared to Samurai 2.
\end{abstract}

Keywords: Sorghum, saline, Rain-fed, marginal, Alternative food. 


\section{PENDAHULUAN}

Sorgum merupakan tanaman pangan bagi masyarakat yang berada di daerah bercurah hujan rendah seperti di benua Afrika dan juga beberapa daerah di Asia. Sorgum relatif mudah beradaptasi pada lahan-lahan marginal seperti lahan dengan salinitas tinggi, tanah masam dengan kadar P rendah, dan juga di lahan kritis lainnya (Hariprasanna \& Patil, 2015; Momongan, Wirnas, \& Sopandie, 2019). Potensi budidaya sorgum ini menjadi acuan bagi bangsa Indonesia untuk terus tetap dikembangkan terutama di daerah dengan kondisi kering, miskin hara dan juga salin. Luas lahan kering yang dapat digunakan untuk pengembangan pertanian di Indonesia tercatat sekitar $30.669,7$ juta hektar dan $6.499,4$ juta hektar berada di Sumatera (Mulyani \& Sarwani, 2013).

Beberapa daerah di Indonesia sejak dulu telah mengenal sorgum bahkan di Sulawesi Selatan, pemerintah setempat terus menggenjot luasan areal penanaman sorgum yang dimanfaatkan bukan hanya sebagai bahan makanan utama namun juga digunakan dalam bentuk olahan (Sirappa, 2003; Susilowati \& Saliem, 2013). Hal ini mendorong pemerintah untuk menghasilkan inovasi terbaru seperti pengembangan varietas untuk kebutuhan pangan, kandungan etanol tinggi, tahan kering namun hingga saat ini belum ada kajian khusus mengenai daya tahan sorgum di lahan berkadar garam tinggi (Balitsereal, 2019; Iriany \& Takdir, 2013).

Tragedi tsunami tahun 2004 masih menyisakan dampak yang sangat nyata bagi masyarakat petani pesisir di Aceh.

Berdasarkan hasil wawancara dengan petani di salah satu desa di kecamatan Samudera Kabupaten Aceh Utara yang terdampak, kenaikan salinitas pada lahan sawah mereka akibat tsunami hingga saat ini belum dapat ditanggulangi. Kenaikan permukaan laut akibat pemanasan global juga berkontribusi terhadap kenaikan tersebut melalui proses intrusi air laut
(Vithanage, Engesgaard, Villholth, \& Jensen, 2011).

Data menunjukkan bahwa potensi lahan suboptimal termasuk lahan kering masam, salinitas tinggi maupun lahan kering iklim kering sekitar 101,9 juta hektar dapat dijadikan lahan pertanian. Lahanlahan tersebut dapat dijadikan perkebunan dan pertanian. Sebagaian besar dari lahan suboptimal terletak di Kalimantan dan Sumatera (Mulyani, Nursyamsi, \& Harnowo, 2016).

Pemahaman mengenai keragaan dan respon sorgum di lahan salin menjadi urgen untuk diteliti lebih lanjut. Dengan demikian diharapkan kajian ini dapat memperkaya khazanah penelitian sorgum dan dapat dijadikan acuan guna mendukung program kemandirian pangan di tingkat nasional. Mewujudkan swasembada pangan khususnya pada tanaman sorgum melalui peningkatan produksi merupakan tantangan pembangunan pertanian masa depan. Melihat besarnya potensi yang dimiliki sorgum, menjadikan sorgum sebagai salah satu tanaman yang terus diteliti dan dikembangkan.

Penelitian ini bertujuan untuk memberdayakan lahan salin untuk budidaya sorgum sebagai solusi dalam upaya deversifikasi dan swasembada pangan diera kenormalan baru dan mengkaji ketahanan beberapa varietas sorgum terhadap salinitas di daerah berpotensi kering tinggi.

Manfaat yang diharapkan adalah dapat menjadi kerangka acuan mengenai ketahanan sorgum terhadap salinitas dan dapat berimplikasi terhadap pengembangan sorgum dilahan marginal dan menjadi tanaman alternatif bagi masyarakat dengan potensi beragam seperti pangan, pakan dan bioenergi.

\section{METODE PENELITIAN}

Penelitian ini dilakukan di Desa Blang Nibong Kecamatan Samudera 
Kabupaten Aceh Utara, Provinsi Aceh pada dilakukan di Laboratorium IlmuIlmu Pertanian Fakultas Pertanian Universitas Malikussaleh. Bahan yang digunakan adalah benih sorgum varietas Numbu dan Samurai2 Pupuk NPK, Insektisida Furadan dan fungisida. Alat yang dipergunakan dalam penelitian ini adalah cangkul, parang/pisau, gembor (alat siram), meteran, ember, jangka sorong, penggaris, timbangan analitik, oven, Ceptometer untuk mengukur luas daun, BWD (Bagan Warna daun) dan alat tulis menulis.Penelitian ini menggunakan Rancangan yang disusun dalam Rancangan Acak Kelompok (RAK), masing-masing 4 ulangan dan 12 tanaman sampel. Dua faktor yang diuji adalah jarak lahan dengan garis pantai dan varietas. Lahan pertama berjarak lebih kurang $100 \mathrm{~m}$ dan lahan kedua berjarak lebih kurang $300 \mathrm{~m}$. Varietas yang diuji adalah Numbu dan Samurai2.

Lahan untuk penanaman dibabat kemudian dicangkul dibersihkan dari rerumputan dan sisa-sisa tanaman yang mengganggu. Pengolahan tanah dilakukan dua kali. Pengolahan pertama yaitu tanah dicankul sedalam kira-kira 20-30 cm, setelah itu dibersihkan dari sisa-sisa tanaman kemudian diratakan. Pengolahan kedua tanah digemburkan dengan cara memecahkan bongkahan-bongkahan hasil olahan tanah pertama sekaligus dilakukan pembuatan bedeng dengan ukuran $240 \mathrm{~cm} \mathrm{x}$ $600 \mathrm{~cm}$.Benih yang digunakan terlebih dahulu diseleksi. Penanaman menggunakan sistim dobled skip row dilakukan dengan cara menugal sedalam $2 \mathrm{~cm}$ dimana dengan jarak tanam $60 \times 20 \mathrm{~cm}$, kemudian benih ditanam dan ditutup dengan tanah gembur kira-kira setebal $1 \mathrm{~cm}$. Setelah Tanaman berumur dua minggu dilakukan penjarangan dengan meninggalkan satu tanaman setiap lubang tanam.

Pemupukan dilakukan satu minggu setelah tanam dengan dosis berdasarkan BWD (bagan warna Daun). Pemeliaraan tanaman yang dimaksud dalam penelitian ini adalah mencakup penyiraman, pengendalian hama dan penyakit, serta tahun 2020. Analisis Laboratorium pengendalian gulma. Penyiraman akan dilakukan dua kali sehari yaitu pada pagi dan sore hari. Untuk mengendalikan hama dan penyakit serta pengendalian gulma akan dilakukan dengan cara manual (hand weeding) dan mekanis (mempergunakan pisau/parang).

Peubah yang diamati yaitu sifat morfologis yang dilakukan setiap seminggu sekali berupa tinggi tanaman dan jumlah daun. Sifat fisiologis yang diamati yaitu LAI dan SPAD. Pengamatan panen dilakukan dengan menghitung biomassa kering dan berat 100 biji. Data diolah menggunakan software $R$ versi $R$ 3.6.2.

\section{HASIL DAN PEMBAHASAN Perubahan Sifat Morfologi Akibat Salinitas}

Pengamatan sifat morfologi menunjukkan pengaruh lahan dan varietas berbeda pada peubah tinggi tanaman, jumlah daun dan BBCH (Gambar 1). Tinggi tanaman sangat dipengaruhi oleh varietas yang diuji. Numbu menunjukkan hasil tertinggi pada kedua lahan $(48.8 \pm 2.47 \mathrm{~cm})$ dibandingkan dengan Samurai2 (34.2 \pm $2.60 \mathrm{~cm})($ Gambar 1).
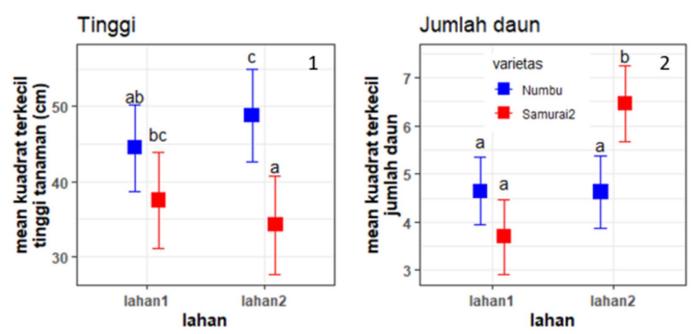

Gambar 1. Mean kuadrat terkecil pengataman sifat morfologi tanaman sorgum. 1) tinggi tanaman dan 2) jumlah daun. Kotak menunjukkan mean kuadrat terkecil. Huruf yang sama tidak berbeda nyata (alpha $=0.05$, disesuaikan-Tukey)

Analisis parameter jumlah daun menunjukkan hal berbeda dimana Samurai2 memiliki daun lebih banyak pada lahan 2 yaitu $6.46 \pm 0.31$ helai sementara pada lahan 2, varietas tersebut menunjukkan nilai 
terendah yaitu $3.69 \pm 0.30$ helai (Gambar 2).
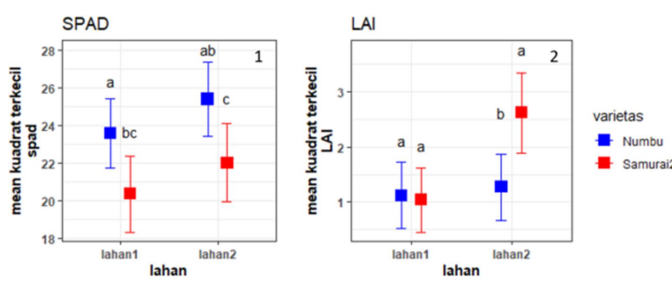

Gambar 2. Mean kuadrat terkecil pengataman sifat fisiologis tanaman sorgum. 1) SPAD dan 2) LAI. Kotak menunjukkan mean kuadrat terkecil. Huruf yang sama tidak berbeda nyata (alpha $=$ 0.05 , disesuaikan-Tukey).

\section{Perubahan Sifat Fiosiologi Akibat Salinitas}

Analisis terhadap sifat fisiologis yang diamati, kedua varietas sorgum menunjukkan respon berbeda pada kedualahan yang diteliti. Pembacaan SPAD atau kehijauan daun dan LAI berbeda nyata antara varietas dan posisilahan (Gambar 2). Numbu menunjukkan tingkat kehijauan daun paling tinggi yang ditunjukkan oleh nilai SPAD, rata-rata yaitu $25.4 \pm 0.78$ sementara terendah dijumpai pada Samurai 2 yaitu $20.4 \pm 0.80$ (Gambar 1). Pola berbeda dijumpai pada pengamatan leaf area index (LAI) dimana Samurai2 mempunyai nilai tertinggi yaitu $2.62 \pm 0.28$ (Gambar 2).

\section{Perubahan Karakteristik Panen Akibat Salinitas}

Analisis data panen menunjukkan respon berbeda terhadap berat kering biomassa dan berat 100 biji (Bagan 3). Berat kering biomassa tidak menunjukkan perbedaan nyataterhadap kedua faktor perlakuan (Gambar 3). Sementara berat 100 biji menunjukkan perbedaan nyata antara varietas Numbu dan Samurai2. Rata-rata berat 100 biji Numbu yaitu $3.54 \pm 0.28 \mathrm{~g}$ sedangkan Samurai2 hanya $1.99 \pm 0.28 \mathrm{~g}$ (Gambar 3).

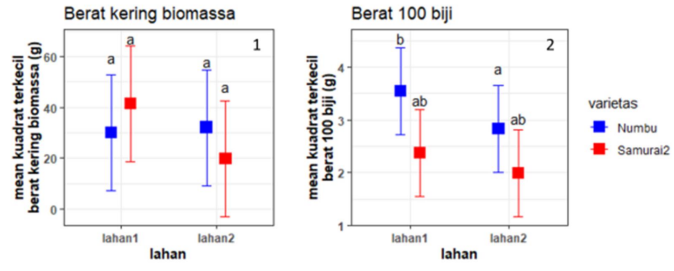

Gambar 3. Mean kuadrat terkecil pengataman aspek panen tanaman sorgum. 1) berat kering biomassa dan 2)berat 100 biji. Kotak menunjukkan mean kuadrat terkecil. Huruf yang sama tidak berbeda nyata (alpha $=0.05$, disesuaikan-Tukey).

\section{Pembahasan}

Penentuan sorgum sebagai salah satu tanaman yang berpotensi sebagai bahan pangan alternatif terutama dalam upaya memanfaatkan lahan-lahan marjinal di Indonesia ditentukan oleh karakter morfologis, fisiologis dan aspek panen. Berdasarkan analisis data menunjukkan bahwa tinggi tanaman, jumlah daun, SPAD, LAI dan berat 100 biji sementara berat kering biomassa tidak menunjukkan perbedaan antara Numbu dan Samurai2 pada dua posisi lahan. Morfologi tanaman tentunya sangat ditentukan oleh lingkungan tumbuh seperti kesuburan tanah, kandungan organik, dalam hal ini adalah tingkat kandungan kadar garam lahan yang digunakan. Faktor penting lainnya adalah tingkat toleransi varietas sorgum terhadap kadar garam atau salinitas. Bagan 1 menunjukkan bahwa Numbu memiliki kecenderungan tinggi terhadap tingkat salinitas menengah hingga tinggi artinya bahwa varietas ini kemungkinan lebih toleran sehingga memberikan respon pertumbuhan yang lebih tinggi dibanding Samurai2. Hal serupa dijumpai pada pengamatan sifat morfofisiologis tanaman sorgum biji untuk mencari genotipe toleran terhadap kekeringan dimana karakter pertumbuhan seperti luas daun bendera, bobot kering daun, dan rasio akar : batang akan menurun bila tingkat cekaman lingkungan tumbuh tinggi (Ali, Abbas, Awan, Jabran, \& Gardezi, 2011; Andriani \& Isnaini, 2013). Hasil uji kadar salin lahan 
menunjukkan nilai pada kisaran $2 \mathrm{dS} / \mathrm{m}$ hingga $15 \mathrm{dS} / \mathrm{m}$ yang tentunya sangat mempengaruhi pertumbuhan dan perkembangan tanaman. Peningkatan kadar garam diatas $10 \mathrm{dSm}$ akan berdampak pada perkecambahan, menghambat perkembangan daun dan akar sehingga pada beberapa sorgum untuk pakan akan mengalami penurunan biomassa secara signifikan (Naim, Mohammed, Ibrahim, \& Suleiman, 2012). Penelitian lain juga menunjukkan adanya pengaruh terhadap pertumbuhan awal tanaman sorgum terhadap peningkatan konsentrasi $\mathrm{NaCl}$ (Ali \& Idris, 2015). Dalam beberapa tahun terakhir, peniliti telah banyak menghasilkan temuan penting dalam penentuan tingkat kehijauan daun seperti chlorophyll meter atau soil plant analysis development (SPAD). Alat ini mampu menentukan status hara seperti $\mathrm{N}$ sehingga mudah melihat kebutuhan unsur $\mathrm{N}$ pada suatu tanaman (Herrera et al., 2016). Asumsi yang dikembangkan adalah bahwa tingginya nilai SPAD maka fotosintat yang dihasilkan dari proses fotosintesis lebih besar sehingga dapat meningkatkan nilai panen sorgum. Numbu menunjukkan nilai SPAD yang lebih tinggi dan hal ini sejalan dengan berat kering 100 biji sebagai indikator panen. Nilai SPAD ini dipercaya sebagai suatu metode dalam menentukan tingkat akumulasi Nitrat dalam daun (Sowinski \& Glab, 2018). LAI atau indeks luas daun juga sangat dipengaruhi oleh unsur hara yang dikandung oleh tanah. Sebagaimana diketahui bahwa tanah marjinal seperti tanah salin cenderung sangat rendah dalam unsur hara dan tinggi unsur pembatas tumbuh seperti kadar garam. Kedua varietas sangat terdampak oleh salinitas lahan yang tergambar jelas pada setiap pengataman termasuk LAI. Meskipun Samurai 2 di lahan 2 menunjukkan nilai LAI lebih tinggi namun tidak berkorelasi positif terhadap karakter panen. Pola serupa ditemukan pada sorgum yang diberikan air laut dan air limbah olahan (GhassemiSahebi et al., 2020).

\section{KESIMPULAN}

Penanaman dua varietas sorgum di lahan salin memberikan dampak berbeda terhadap sifat morfologis, fisiologis dan panen. Numbu menunjukkan pertumbuhan tinggi tanaman, SPAD, dan berat100 biji lebih tinggi pada kedua lahan yang dicobakan. Kesimpulan sementara dapatlah dikatakan bahwa Numbu lebih toleran pada lahan salin dibandingkan dengan Samurai2. Tentunya hal ini harus dikaji lebih dalam sehingga dapat dikatakan bahwa tanaman sorgum berpotensi tinggi dalam pemanfaatan lahan salin.

\section{UCAPAN TERIMAKASIH}

Penelitian ini Dibiayai dengan Dana Pendapatan Negara Bukan Pajak (PNBP) dalam Daftar Isian Pelaksanaan Anggaran (DIPA) Universitas Malikussaleh Tahun Anggaran 2020.

\section{DAFTAR PUSTAKA}

Ali, M. A., Abbas, A., Awan, S. I., Jabran, K., \& Gardezi, S. D. A. (2011). Correlated response of various morphophysiological characters with grain yield in sorghum landraces at different growth phases. Journal of Animal and Plant Sciences, 21(4), 671-679.

Andriani, A., \& Isnaini, M. (2013). Morfologi dan Fase Pertumbuhan Sorgum. Sorgum : Inovasi Teknologi dan Pengembangan, (1), 47-68.

Balitsereal. (2019). Laporan Kinerja Balai Penelitian Tanaman Serelia.

Ghassemi Sahebi, F., Mohammadrezapour, O., Delbari, M., KhasheiSiuki, A., Ritzema, H., \& Cherati, A. (2020). Effect of utilization of treated wastewater and seawater with Clinoptilolite-Zeolite on yield and yield components of sorghum. 
Agricultural Water Management, 234(November 2019), 106117. https://doi.org/10.1016/j.agwat.2020. 106117.

Hariprasanna, K., \& Patil, J. V. (2015). Sorghum: origin, classification, biology and improvement. In Sorghum molecular breeding (pp. 320). Springer, New Delhi.

Herrera, J. M., Rubio, G., Häner, L. L., Delgado, J. A., Lucho-Constantino, C. A., Islas-Valdez, S., \& Pellet, D. (2016). Emerging and established technologies to increase nitrogen use efficiency of cereals. Agronomy, $6(2)$, 11-18. https://doi.org/10.3390/agronomy 6020025 .

Iriany, R. N., \& Takdir, M. a. (2013). Asal Usul dan Taksonomi Tanaman Sorgum. Balai Penelitian Tanaman Serealia, 1- 12.

Momongan, J. D., Wirnas, D., \& Sopandie, D. (2019). Potensi Hasil dan Toleransi Galur-galur Inbrida Sorgum pada Tanah dengan Hara Fosfor Rendah Yield Potential and Tolerance of Soghum Inbred Lines to Low Phosphorus Soil, 47(April), 3946.

Mulyani, A., Nursyamsi, D., \& Harnowo, D. (2016). Potensi dan Tantangan Pemanfaatan Lahan Suboptimal untuk Tanaman Aneka Kacang dan Umbi. In Prosiding Seminar Hasil Penelitian Tanaman Aneka Kacang dan Umbi.

Mulyani, A., \& Sarwani, M. (2013). Karakteristik dan Potensi Lahan Sub Optimal untuk Pengembangan Pertanian di Indonesia. Jurnal Sumberdaya Lahan, 7.
Naim, A. M. El, Mohammed, K. E., Ibrahim, E. A., \& Suleiman, N. N. (2012). Impact of Salinity on Seed Germination and Early Seedling Growth of Three Impact of Salinity on Seed Germination and Early Seedling Growth of Three Sorghum ( Sorghum biolor L . Moench ) Cultivars. Science and Technology, (May 2014). https://doi.org/10.5923/j.scit.2012020 2.03.

S Ali, \& Idris, A. (2015). Response of Sorghum ( Sorghum bicolor L .) Cultivars to Salinity Levels at Early Growth Stages. Journal of Agricultural Science and Engineering, 1(1), 11-16.

Sirappa, M. P. (2003). Prospek pengembangan sorgum di indonesia sebagai komoditas alternatif untuk pangan, pakan, dan industri. Jurnal Litbang Pertanian, 22(4), 133-140.

Sowinski, J., \& Glab, L. (2018). The effect of $\mathrm{N}$ fert management on yield and nitrate content in sorghum biomass. Field Crops Research, 227, 132-143. https://doi.org/10.1016/j.fcr.2018.08. $\underline{006 .}$

Susilowati, S. H., \& Saliem, H. P. (2013). Perdagangan Sorgum di Pasar Dunia dan Asia serta Prospek Pengembangannya di Indonesia. Agro Inovasi, 1-17.

Vithanage, M., Engesgaard, P., Villholth, K. G., \& Jensen, K. H. (2011). The Effects of the 2004 Tsunami on a Coastal Aquifer in Sri Lanka, 1-11. https://doi.org/10.1111/j.17456584.2 011.00893.x. 